МЕХАНІЗМ ФОРМУВАННЯ ПОЛІТИКИ ЗБАЛАНСОВАНОГО ЕКОНОМІЧНОГО РОЗВИТКУ ТЕРИТОРІЙ

\title{
MECHANISM OF POLICY FORMATION OF THE TERRITORIES BALANCED ECONOMIC DEVELOPMENT
}

\begin{abstract}
у статті запропоновано механізм фрормування політики збалансованого економічного розвитку територій. Проаналізовано концептуальні підходи до визначення сутності збалансованого економічного розвитку територій. Визначено та обрунтовано основні елементи розробленого механізму формування політики збалансованого економічного розвитку територій, серед яких: суб'єкти, які зацікавлені в підвищенні рівня збалансованого економічного розвитку територій, та об'єкти в якості ссрормованої програми та проекту регіонального розвитку; ключова мета; принципи; фрункції; форми; важелі; інструментарій в якості засобів впливу на об'єкт із метою підвищення рівня збалансованого економічного розвитку територій; концептуальний базис як систематизована сукупність кроків, дій, які необхідно здійснювати у напрямку підвищення конкурентоспроможності регіону; складові державної політики; забезпечення збалансованого економічного розвитку територій; рівні формування політики та чинники збалансованого економічного розвитку територій, які потрібно враховувати при формулюванні ключової мети

Ключові слова: економічний розвиток, регіональний розвиток, збалансований розвиток, державна політика, інструменти, механізм.
\end{abstract}

В статье предложен механизм фрормирования политики сбалансированного эко- номического развития территорий. Проанализированы концептуальные подходы к определению сущности сбалансированного экономического развития территорий. Определены и обоснованы основные элементы разработанного механизма фрормирования политики сбалансированного экономического развития территорий, среди которых: субъекты, заинтересованные в повышении уровня сбалансированного экономического развития территорий, и объекты в качестве сфрормированной программы и проекта регионального развития; ключевая цель; принципы, срункции; фрормы; рычаги; инструментарий в качестве средств воздействия с челью повышения уровня сбалансированного экономического развития; концептуальный базис как систематизированная совокупность шагов, действий, которые необходимо осуществлять в направлении повышения конкурентоспособности региона; составляющие государственной политики; обеспечение сбалансированного экономического развития; уровни формирования политики и фракторы сбалансированного экономического развития территорий, которые нужно учитывать при формулировании ключевой чели.

Ключевые слова: экономическое развитие, региональное развитие, сбалансированное развитие, государственная политика, инструменты, механизм.

Ukrainian Engineering

and Pedagogical Academy

A mechanism for forming a policy of territories balanced economic development is proposed in the article. The necessity to change approaches to the formation and implementation of economic development policy is due to the heterogeneity of the regions socio-economic situation and the different speed of regional economic subsystems development. The main goal of this article is to develop the mechanism of policy formation of territories balanced economic development and substantiation of its key elements. This study combines using such methods: a theoretical generalization, analysis and synthesis, induction and deduction - to clarify the essence of territories balanced economic development; system and process approaches - to develop the mechanism of policy formation; the method of formalization - to substantiate the elements of the proposed mechanism. As a result of the analysis of the terminological apparatus, the essence of balanced economic development is clarified. It is substantiated that the equilibrium state of the economic system is its stable state under constant external conditions and parameters, which is characterized by the lack of incentives for economic entities to change economic behavior, while maintaining their subordination and balance of resources in time and space. It is determined that the emergence of new approaches to conceptualize the problem situation, analyze dynamic processes, identify transients, describe in detail the simulated situations, using the principles of synergy, is the basis for the development of sustainable economic development. It is substantiated that in the conditions of resource constraints and crisis processes the strategy of economic development at the regional level should be determined only taking into account the indicators of the optimal balance of economic, natural resource and social factors of economic systems. Covering a range of different legislative, administrative and economic measures taken by local authorities, it was determined that public policy is aimed at regulating and optimizing the processes taking place within the region, between regions, and between the region and the state.

Key words: economic development, regional development, balanced development, state policy, tools, mechanism.

Постановка проблеми. Однією із передумов глибоких транссормаційних перетворень в Україні є зміна державної регіональної політики та модернізація діяльності інститутів влади на регіональному рівні. Процеси зміни основ регіонального управління, що останнім часом розпочалися в Україні, хоча і мають певні позитивні зрушення, але через зростання територіальної дисреренціації в економічному розвитку та соціальному забезпеченні громадян, стали ще більш актуальними. Необхідність зміни принципів формування та реалізації політики економічного роз- витку територій обумовлюється неоднорідністю соціально-економічного становища регіонів та різною швидкістю розвитку регіональних економічних підсистем. Наявність істотних диспропорцій розвитку регіонів України підтверджує розмах асиметрії основних показників рівня соціально-економічного розвитку. Враховуючи те, що поряд з економічними фокторами ефективний регіональний розвиток залежить від наявності та фуннкціонування системи інститутів, актуальності набуває завдання теоретичного дослідження умов збалансованого розвитку, причин регіональної асиметрії 
та узагальнення досвіду державного регулювання економічного розвитку територій.

Аналіз останніх досліджень та публікацій. Питанням державного регулювання економічного розвитку присвячені напрацювання таких науковців, як: Л. Абалкін, В. Бакуменко, В. Князєв, Ю. Ковальчук, А. Кузнєцов, Т. Морозова, Е. Плисецкий, А. Стельмащук, Ю. Сурмі та інші автори. При цьому обґрунтування інструментів регіонального розвитку детально розглянуто в роботах В. Вакуленка, О. Берданової, В. Кравців, С. Романюка. Проблематика забезпечення збалансованого розвитку регіонів дискутується в роботах зарубіжних та вітчизняних вчених, серед яких: В. Бєлкін, О. Говтвань, В. Івантер, Г. Клейнер, Ю. Лейбкинд, В. Перламутров. Фактичне застосування самого поняття «збалансований розвиток» в управлінських практиках, його наповнення економічним змістом, реалізація принципу збалансованості в інституціональних механізмах, є питанням теоретико-методологічним. У цьому аспекті важливим $€$ також встановлення співвідношення понять «сталий», «збалансований», оскільки їх часто не відрізняють та правильно не ідентифікують. Окрім цього, поза увагою теоретиків та практиків залишається аспект формування політики збалансованого економічного розвитку територій.

Постановка завдання. У зв'язку з зазначеним вище, метою статті $€$ розробка механізму фрормування політики збалансованого економічного розвитку територій та обґрунтування його ключових елементів.

Виклад основного матеріалу. Перш ніж перейти до процесу розробки механізму, слід визначити сутність та зміст поняття «збалансований економічний розвиток територій». Так, відповідно до Сучасного економічного словника, під збалансованістю в економіці розуміється рівновага, тобто стан економічної системи, що характеризується урівноваженням двох або більшого числа різноспрямованих фракторів [10, с. 266]. Однак, на думку Г. Клейнера, ототожнення понять «збалансованість» і «рівновага» по відношенню до економічної системи не зовсім є правомірним, адже різниця виникає через нееквівалентність понять «система» і «стан системи». При цьому, поняття системи носить якісний, дискретний характер, в той час як поняття стану - кількісний і, як правило, безперервний характер. У цьому контексті цілком логічним $€$ віднесення збалансованості до характеристик системи, а рівноваги - до характеристик її стану. Таким чином, збалансованість економічної системи, на думку Г. Клейнера, визначається як відповідність, пропорційність структурних компонент економічної системи, що забезпечують їі стійке функціонування. Тобто в загальному випадку поняття збалансованості можна розглядати одночасно і як статичне, структурне, що відображає співвідношення між компонентами економічної системи, так і як динамічне, що відображає збереження тих або інших істотних властивостей (параметрів) системи при певних впливах на систему.

Необхідно акцентувати увагу, що в період розвитку радянської економіки однією 3 ключових категорій в науці була «народногосподарська збалансованість». Відповідно до напрацювання В. Бєлкіна, під збалансованістю розуміється не тільки забезпечення матеріальних пропорцій у відповідному плані, необхідним є досягнення відповідності між доходами населення і обсягами товарів і послуг, доходами державного бюджету і їх матеріальним покриттям, доходами підприємств і колгоспів і їх фрінансовим покриттям [2, с. 334]. У свою чергу, фрінансово-вартісна збалансованість передбачає відповідність кожної із складових частин суспільного продукту і національного доходу за вартістю і в натуральному вираженні: відповідність грошових доходів населення і обсягу придбаних на них товарів і послуг, відповідність грошових доходів держави, підприємств і колгоспів матеріальних ресурсів, призначеним на накопичення й інші, державні та громадські потреби, забезпечення експортом валютних ресурсів для покриття імпорту. На думку вченого, тільки в цьому випадку може бути забезпечено нормальне відтворення, під яким розуміється реалізація суспільного продукту і національного доходу [2, с. 340]. Інші російські вчені (О. Говтвань, В. Ивантер, Ю. Лейбкінд, В. Перламутров) стверджували, що економічна збалансованість представляє собою багатошарові відносини між виробництвом і його матеріальним забезпеченням, між випуском продукції і її використанням, накопиченням і капітальним вкладенням, капітальним вкладенням і основними фрондами, основними фондами, поточними витратами матеріальних ресурсів і живою працею [4]. Науковці також виокремлювали таке поняття як «фрінансововартісна збалансованість», яка визначалась в 2-х напрямах: як відповідність обсягу платіжних засобів системи матеріальним потокам всередині системи; як збалансованість витрат фрінансових ресурсів галузями комплексу та їх надходжень в систему.

Отже, в період розвитку радянської економіки першочерговим розумінням під збалансованістю було забезпечення матеріально-фрінансової рівноваги народного господарства. Окрім цього, національна статистика ґрунтувалася на балансовому методі, який цілком аргументовано критикував відомий американський економіст та лауреат Нобелівської премії (за розвиток методу «витрати - випуск» і його практичне застосування до важливих економічних проблем) В. Леонтьєв. Розроблена ним методика передбачала комплексне статистичне відображення структурних взаємозв'язків, що визначають потоки товарів і послуг між усіма секторами, а також вирішення великих систем математичних 
рівнянь. Слід зазначити, що в країнах ЄС його таблиці «витрати-випуск» $є$ обов'язковим елементом статистичної бази. Але на сьогодні запропоновані урядом нововведення в економічній політиці неможливо адекватно оцінити через відсутність якісної галузевої статистики.

Слід зазначити, що ідею збалансованого розвитку взяли на озброєння у різних країнах, де розробляють стратегії сталого розвитку на глобальному, національному, регіональному, місцевому рівнях управління. Врахування принципу збалансованості дало позитивні результати, значно поліпшуючи управління в містах і селах і забезпечуючи збалансованість економічного, соціального та екологічного розвитку [9]. При цьому кращі результати досягнуто там, де в розробленні й реалізації стратегій збалансованого місцевого розвитку та розгляді управлінських рішень щодо проблем, що стосуються як спільноти, так і окремої людини, беруть активну участь місцеві громади. У той же, час слід розуміти, що масова і ефективна соціальна мобілізація для збалансованого місцевого розвитку можлива лише за умови усвідомлення широким загалом його концептуальних основ, шляхів реалізації, нормативно-правових, інституційних, матеріальних засад, внутрішніх і зовнішніх політичних та економічних умов [11]. Аналіз історії становлення концепції збалансованого розвитку дозволив визначати ключові етапи цього процесу та його особливості. Так, ключовим координатором в аспектах збалансованості є Організація об'єднаних націй $(\mathrm{OOH})$, яка не тільки переймається розв'язанням глобальних проблем, виявленням загроз та пошуком інструментів для їх усунення, але й питаннями світової співдружності. 3 аналізу процесу становлення концепції збалансованого розвитку простежується логічний перехід до екологізації наукових знань і соціально-економічного розвитку територій. Слід зазначити, що Україна, як і інші країни-члени ООН, приєдналася до глобального процесу забезпечення сталого розвитку.

Необхідно акцентувати увагу, що в даний час економічна категорія «збалансованість» розуміється інакше. Головною метою сучасної економічної політики є макроекономічна стабільність, яка передбачає збалансований державний бюджет і дуже низьку інсрляцію. Але уряд в період кризових процесів балансує бюджет шляхом жорсткого скорочення витрат. Позначивши історичні контури збалансованості, визначимо, що в сучасних умовах найбільш адекватними є підходи еволюційної теорії, що дозволяють розглядати економіку як динамічну систему, яка росте, розвивається і вдосконалюється. Ця теорія базується на врахуванні всіх чинників і умов, які реально впливають на економічні процеси.

Поява нових підходів, що дозволяють здійснювати концептуалізацію проблемної ситуації, ана- лізувати динамічні процеси, виділяти перехідні явища, детально описувати ситуації, що моделюються, з застосуванням принципів синергії, є основою розвитку питань управління збалансованим економічним розвитком територій.

Слід зазначити, що в умовах модернізації економіки нові підходи до процесів забезпечення збалансованого економічного розвитку територій фрормуються відповідно до вимог ринкових перетворень. Для організаційних управлінських структур економічних систем на рівні регіону, що базуються на існуючій нормативно-правовій базі, природних, трудових та орінансових ресурсах, вкрай важливим $€$ визначення сценарних прогнозів і виявлення перспективних напрямків, що забезпечують ефрективний економічний розвиток. У свою чергу, міжнародний поділ праці, глобалізація економіки, посилення конкуренції, обмеженість інвестиційного та природно-ресурсного потенціалів істотно впливають на збалансований розвиток соціально-економічних систем в довгостроковій перспективі. Науковий аналіз світового досвіду свідчить про те, що розробка проблеми збалансованого розвитку регіонів в умовах відсутності рівноваги і адаптації економічної системи до циклічних змін в економіці обумовлена об'єктивною природою циклів, яку важливо враховувати економічним суб'єктам для створення умов зниження наслідків економічних протиріч, впровадження передових технологій і підтримки інноваційної діяльності.

В умовах ресурсних обмежень і кризових процесів стратегію економічного розвитку на регіональному рівні необхідно визначати тільки з урахуванням показників оптимального балансу економічних, природно-ресурсних і соціальних фракторів розвитку економічних систем. Прогнозні оцінки дозволять виявити умови економічного зростання і забезпечити оптимізацію системи економічних та інституційних заходів. Але специфрічні особливості територіальних економічних систем вимагають розробки і апробації відповідних концептуальних і методологічних підходів визначення співвідношення між повноваженнями державних, галузевих і корпоративних структур, відновлення економічних зв'язків на мезо- і мікрорівнях економіки.

Охоплюючи комплекс різних законодавчих, адміністративних і економічних заходів, що проводяться місцевими органами влади, було визначено, що державна політика спрямована на регулювання і оптимізацію процесів, що відбуваються всередині регіону, між регіонами, а також між регіоном і державою. Така гармонізація, прагнення до досягнення балансу особливо важливі при наявності нерівноважних процесів, що постійно відбуваються в регіоні. Саме стійкість є основоположною умовою уникнення певної території кризового стану. Однак досягнення стійкості розвитку обумовлено низкою чинників, які так чи інакше залежать 
від кон'юнктури ринку і різка їх зміна тягне за собою втрату стійкості регіоном. Більш жорсткою визначальною умовою стійкості розвитку регіону виступає збалансованість його ресурсного потенціалу. При цьому збалансованість фрормується і визначається відповідно до визначеного вектору розвитку території. Оцінка збалансованості передбачає виявлення пропорцій між чинниками, що визначають економічний розвиток території.

Отже, рівноважний стан економічної системи це ії стабільний стан при незмінних зовнішніх умовах і параметрах, що характеризується відсутністю у господарських суб'єктів стимулів зміни економічної поведінки, при збереженні їх субординації і балансу ресурсів у часі і просторі. При рівновазі задається певний рівень розвитку науки і техніки, технологічності виробництва, постулюється результативність параметрів науково-технічного прогресу в даний момент часу. Тому збалансований розвиток територій країни є одним з декларованих в даний час пріоритетів державної політики країни, що, зокрема, знаходить вираз у розроблюваних і прийнятих державними органами та органами місцевого самоврядування програмних документах і нормативних актах. У той же час збалансований розвиток виступає в якості стратегічної мети державної політики, сутність якої полягає в оптимальному використанні обмежених ресурсів та застосуванні енергозберігаючих технологій.

Слід зазначити, що сучасні тенденції негативно впливають на функціонування регіональних систем і національної економіки в цілому. Проблеми регіонального розвитку займають центральне місце в державній політиці, що обумовлено значимістю внеску регіонів в загальний розвиток країни. Основні заходи політики спрямовані на збалансований розвиток територій, разом 3 тим на тлі загострення економічної обстановки відзначається поглиблення диференціації регіонального розвитку, в зв'язку з чим, необхідним є вивчення зарубіжної практики для її запозичення і модифрікації з урахуванням особливостей вітчизняної економіки.

Світовий досвід розвитку територій різниться в залежності від країни і відповідно має свою специфріку, що обумовлює неможливість його застосування в чистому вигляді. Однак деякі елементи і інструменти регіональної політики, адаптовані до умов сучасної економіки, можуть мати позитивний результат. Вибір заходів впливу на розвиток депресивної території заснований на активізації власного потенціалу, нівелюванні слабких і посиленні сильних сторін. Узагальнення інфрормації щодо особливостей регіональної політики зарубіжних країн з управління підтвердило доволі велику кількість інструментів регіональної політики та різну спрямованість заходів держави в рамках розвитку територій. Так, регіональна політика Китаю відрізняється максимальною конкретизацією заходів і поетапною їх реалізацією. Основою регіональної політики Японії індикативного планування закріплене на законодавчому рівні. Специоріка політики США полягає в адресності та переважному вирішенні локальних проблем. Регіональна політика Швеції та Нідерландів реалізується за допомогою державних регіональних компаній, сорормованих для управління розвитком проблемних територій. У Німеччині регіони самі розробляють заходи щодо досягнення планових показників розвитку відповідно плану федерального сприяння. У Великобританії найважливіші напрямки територіального розвитку закріплені на законодавчому рівні, окрім цього найважливішим інструментом регіональної політики є гранти. Відзначимо, що для зарубіжних країн регіональна політика є явищем постійним, що, в свою чергу, визначає розвиненість і різноманітність існуючих інструментів і заходів.

Історичний досвід багатьох держав світу свідчить про домінування конкретних складових регіональної політики в різні періоди часу. Так, в період економічного зростання основна увага приділяється складовій вирівнювання, а в кризовий період, навпаки, - стимулювання територій зі значним «інерційним» ефректом поширення потенціалу зростання. Під час структурних змін в економіці держави територіальна дисреренціація розвитку завжди посилюється, особливо в період відновлення економічного зростання. Це важливо врахувати при розробці механізму формування політики збалансованого економічного розвитку територій.

Окрім цього виявлено, що незважаючи на відмінність підходів до забезпечення збалансованого економічного розвитку територій, спостерігаються схожі риси. Зокрема, залучення інструментів бюджетно-фрінансової системи при посиленні стимулюючої фрункції, розвиток інноваційної діяльності, регіональних ініціатив та найбільш ефрективного використання потенціалу території. Перенесення позитивної практики зарубіжних країн для українських регіонів можливе за рахунок наділення територій більшою самостійністю, зміцнення законодавчих засад щодо забезпечення збалансованого розвитку, максимальної конкретизації заходів підтримки для посилення узгодженості взаємодії суб'єктів, збільшення інвестицій в розвиток людського потенціалу та інноваційної активності, розширення економічно активних зон, розробки моделей диференціації регіонів на основі удосконаленої індикативної системи для вироблення найбільш ефективних заходів. У цьому контексті для результативного впливу держави на економічний розвиток територій необхідно створити і впровадити відповідний механізм.

Слід акцентувати увагу, що деякі вчені трактують механізм як сукупність організаційних та економічних фрорм і методів пов'язаних в єдиний порядок якого-небудь виду діяльності [8]. Особливості 
термінологічних та методологічних аспектів щодо визначення «механізму» наводиться в [13], який пропонують визначати з позиції процесного підходу, що передбачає можливість його конструювання стандартними способами та прийомами функціонального моделювання. У своїх міркуваннях ми додержуємося думки про те, що «забезпечення» виступає одним з елементів механізму, дієвим важелем запуску його принципової дії, необхідним компонентом, що узгоджує інтереси керуючої та керованої підсистеми із чинниками зовнішнього та внутрішнього середовища. Враховуючи те, що регіональна політика представляє собою сукупність законодавчих, адміністративних та економічних заходів, спрямованих на усунення економічного дисбалансу між регіонами з метою досягнення оптимального розміщення виробничих сил і населення на території країни, механізм фрормування політики збалансованого економічного розвитку територій можна визначити як сукупність заходів адміністративного і організаційного характеру, спрямованих на збалансоване фрункціонування як окремого регіону, так і всіх територій країни, за допомогою розробки і реалізації управлінських рішень. Основною метою даного механізму є створення умов для забезпечення збалансованого економічного розвитку територій країни та досягнення стратегічних цілей їх розвитку територій. Отже, структуру механізму фрормування політики збалансованого економічного розвитку територій візуалізовано на рис. 1.

У запропонованому механізмі відображено основні елементи процесу фрормування політики збалансованого економічного розвитку територій. Науковим підґрунтям механізму виступають концептуальний базис, функції та принципи збалансованого економічного розвитку територій. Структурними елементами механізму є компоненти, які на національному рівні призначені для тих, хто розробляє політику, планує систему, фрінансує цю діяльність і приймає рішення.

Компоненти регіонального рівня призначені для керівників служб і програм, а також для осіб, які приймають рішення.

Слід зазначити, що фрормулювання ключової мети політики збалансованого економічного розвитку територій та обґрунтування пріоритетів пов'язано з конкретними умовами, в яких фрункціонує певна територія, з її можливостями, з системою викликів внутрішнього і зовнішнього середовища (чинники, ресурси, можливості, загрози). Визначено суб'єкти фрормування та реалізації збалансованої економічної політики на національному, регіональному та місцевому рівнях.

Теоретичні основи концептуального моделювання збалансованого економічного розвитку територій доцільно представити через принципи загальної теорії систем. 3 урахуванням адаптації основних постулатів зазначеної теорії до функціонування національного господарства в основу економічного розвитку країни повинні бути покладені три ключові принципи: 1) стійкості, який передбачає здатність системи забезпечувати виконання своїх фрункцій, досягати поставлених цілей, зберігати всю сукупність своїх властивостей; 2) пропорційності, який визначає раціональне закономірне кількісне і якісне співвідношення в ній систем і елементів за критерієм відповідності максимальної комплексної результативності та ефективності фрункціонування; 3) інноваційності, який характеризує здатність трансорормуватися в новий якісний стан, адаптуватися до нових умов існування при переході до економіки, заснованої на знаннях.

Також виокремлюють принципи інтегрованості та гнучкості. Так, принцип інтегрованості вказує на пов'язаність політики збалансованого економічного розвитку територій з загальнодержавною та регіональною стратегіями. Принцип гнучкості передбачає узгодження інтересів на компромісній основі з метою вирішення великої сукупності територіальних проблем. Політика збалансованого економічного розвитку територій має бути узгоджена відповідно до часу, ресурсів, пріоритетів. Відносини між інституціями мають будуватися на основі партнерства і співробітництва.

Слід зазначити, що при реалізації принципу пропорційності в основу структурної політики доцільно покласти підхід, який передбачає, що економічний розвиток являє собою процес безперервних структурних змін, що супроводжуються ефректами компенсації і заміщення. Що стосується концепції інноваційної транссормації, слід виділити такі головні аспекти: базис перетворень (галузевий комплекс, який $є$ ключовою ланкою економічної системи); спосіб технологічних перетворень (передбачає розвиток виявлених потенційних точок зростання економіки територій); система стимулювання і підтримки інноваційної діяльності (формування сприятливої екосистеми, спрямованої на актуалізацію науково-технологічного потенціалу в різних секторах економіки і сорерах діяльності.

Концепція збалансованого розвитку передбачає гармонійний стійкий пропорційний розвиток регіону завдяки якому використання природних ресурсів, визначення напрямку інвестування, врахування науково-технічного розвитку та існуючі інституційні зміни узгоджені між собою. В рамках концепції збалансованого розвитку загальновизнаним методологічним підходом до моніторингу сталого розвитку є методологія ООН.

Серед чинників збалансованого економічного розвитку необхідно виділити наступні [2; 5; 7]: зміна кількісних та якісних характеристик продуктивних сил національної економіки; зміна технології їх споживання; зміни в реальному секторі економіки, спричинені зміною структури або величини 


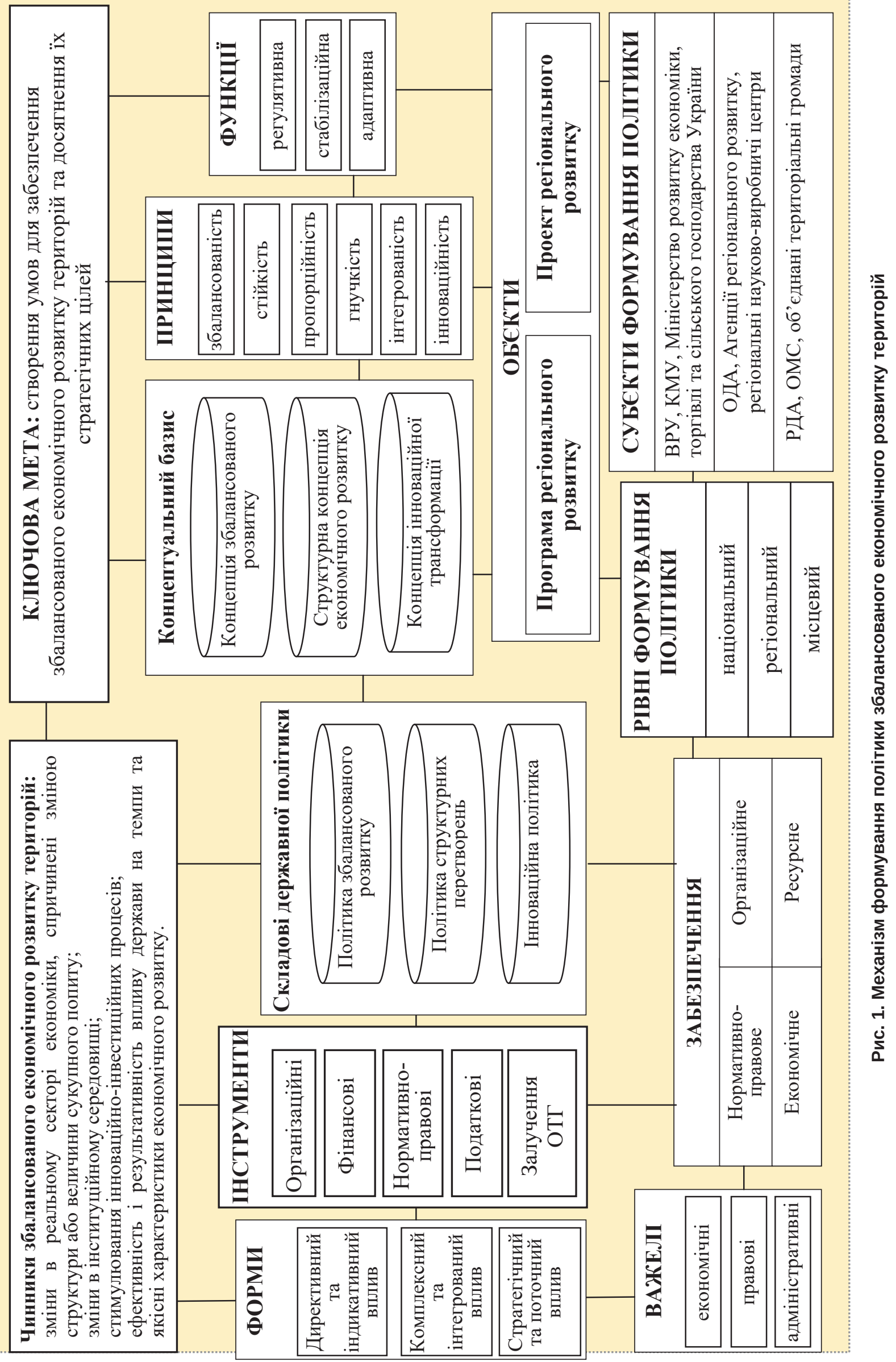


сукупного попиту; зміни в інституційному середовищі; психологічні настрої та сприйняття економічними суб'єктами поточної економічної ситуації та можливих варіантів подальшого розвитку; стимулювання інноваційно-інвестиційних процесів, наслідком яких $€$ оптимізація структури економіки країни; еорективність і результативність впливу держави на темпи та якісні характеристики економічного розвитку шляхом застосування певних інструментів державного впливу.

В контексті визначених стратегічних цілей та завдань для їх реалізації, а також з урахуванням особливостей сучасного розвитку територій, найбільш пріоритетними інструментами державного управління економічним розвитком $є$ наступні:

- в рамках організаційних - поширення практики застосування державно-приватного партнерства для вироблення рішень в області інвестування в технічне переобладнання інфраструктури; формування виконавчих комітетів обласних рад, що включають представників регіональної влади, бізнесу і ОТГ; фрормування спеціальних фрондів, призначених для згладжування негативного впливу несприятливої кон'юнктури сировинних ринків і спрямованих на розвиток високотехнологічних виробництв;

- в рамках нормативно-правових - розробка нормативно-правової бази, що дозволяє здійснювати зміну структури доходів території, підвищує частку коштів; укладання договорів між регіональною владою та ОТГ;

- в рамках податкових - система податкових пільг для підприємств, що здійснюють технологічні інновації та фрормують високопродуктивні робочі місця, а також впроваджують заходи по збереженню природного середовища;

- в рамках фрінансових - фрормування системи цільових трансорертів, призначених для стимулювання діяльності промислових підприємств та технологічне переозброєння промисловості; фрінансування у вигляді грантів і субсидій.

Форми державного регулювання розвитку територій визначаються в характері застосування регулюючого впливу. Форми державного регулювання розвитку територій можна класифікувати як:

- директивний та індикативний вплив. Директивний вплив передбачає виконання обов'язкових норм та вимог регулятора. Директивно може бути здійснено прямий і непрямий вплив. Індикативний вплив спрямовано як на діяльність господарюючих суб'єктів, так і на регулювання умови господарювання. Індикативний вплив, як правило, ґрунтується на стимулюючих заходах державного регулятора;

- комплексний і інтегрований вплив. Комплексний вплив полягає в регулюванні всього комплексу як складної економічної сфрери життєдіяльності. Подібне регулювання включає в себе всю сукупність господарських зв'язків, ґрунтується на системному аналізі;

- стратегічний та поточний вплив. Стратегічний вплив передбачає вирішення довгострокових завдань і реалізацію довгострокових проектів. Поточне дія заснована на оперативному реагуванні держави на певні проблеми, завдання, умови господарювання, що виникають в окремих галузях економіки.

Отже, запропонований механізм характеризується наступними ключовими елементами є: суб'єкти, зацікавлені в підвищенні рівня збалансованого економічного розвитку територій; об'єкти програма та проект регіонального розвитку; принципи - основні правила й рекомендації, які повинні враховуватися й виконуватися в процесі економічного розвитку територій; концептуальний базис - систематизована сукупність кроків, дій, які необхідно здійснювати у напрямку підвищення конкурентоспроможності регіону; складові державної політики - напрямки державної підтримки регіонів; інструменти - засоби впливу на об'єкт із метою підвищення рівня збалансованого економічного розвитку територій; функції, фрорми та важелі; забезпечення збалансованого економічного розвитку територій; рівні формування політики та чинники збалансованого економічного розвитку територій, які потрібно враховувати при фрормулюванні ключової мети.

Висновки 3 проведеного дослідження. Таким чином, обґрунтовано концептуальні засади побудови та фрункціонування механізму фрормування політики збалансованого економічного розвитку територій. Запропонований механізм передбачає, що фрормування політики збалансованого економічного розвитку територій відбувається у єдності із загальною стратегією розвитку регіону та з урахуванням системи стратегічного управління збалансованим економічним розвитком територій, що дозволить забезпечити адресну допомогу перспективним галузям виробництва в контексті стимулювання ендогенного економічного зростання. У межах механізму розширено типізацію інструментарію державного управління та враховано чинники збалансованого економічного розвитку територій.

\section{БІБЛІОГРАФІЧНИЙ СПИСОК:}

1. Бакуменко В. Методологія державного управління: проблеми становлення та подальшого розвитку / Бакуменко В., Князєв В., Сурмі Ю. // Вісник УАДУ. - 2000. - № 1. - С. 11-27.

2. Белкин В.Д. Избранные труды в 3 т. Том 2. Параллельный рубль и системная сбалансированность экономики / В. Д. Белкин // Центральный эконом.математич. ин-т РАН. - М. : ЦЭМИ РАН, 2015. - 616 с.

3. Берданова О.В. Інструменти регіонального розвитку в Україні / Берданова О.В., Вакуленко В.М. - К.: НАДУ, 2013. - 286 с. 
4. Говтвань О.Д. Сбалансированность народнохозяйственных комплексов (на примере продовольственного комплекса) / Говтвань О.Д., Ивантер В.В., Лейбкинд Ю.Р. и Перламутров В.Л. - М.: ЦЭМИ АН СССР, 1984. - C. 4- 5.

5. Клейнер Г. Б. Системная сбалансированность экономики: методы анализа и измерения / Г. Б. Клейнер // Стратегическое планирование и развитие предприятий: Секция 1 / Материалы Шестнадцатого всероссийского симпозиума. Москва, 14-15 апреля 2015 г. - Москва : ЦЭМИ РАН, 2015. - С. 74-78.

6. Колпаков В.М. Методы управления / Колпаков В.М. - . К. : МАУП, 2003. - 368 С.

7. Кравців В. С. Територіальний розвиток та регіональна політика в Україні: актуальні проблеми, ризики та перспективи адміністративно-фрінансової децентралізації / НАН України. ДУ «Інститут регіональних досліджень імені М.І. Долішнього НАН України»; наук. редактор В.С. Кравців. - Львів, 2017. - 120 с.

8. Музиченко А.С. Організаційно-економічний механізм стимулювання інноваційної діяльності в АПК / Музиченко А.С., Малюга Л.М. // Економіка АПК. - 2009. - № 11. - С. 38-43.

9. Плисецкий Е.Л. Зарубежный и отечественный опыт государственной поддержки развития территории / Плисецкий Е.Л. // Региональная экономика: теория и практика. - 2014. - № 42(369). - С. 32-44.

10. Райзберг Б.А. Современный экономический словарь / Райзберг Б.А., Лозовский Л.Ш., Стародубцева Е.Б. - М.: ИНФРА-М, 2006. - 480 с.

11. Романюк С.А. Розвиток регіонів у відкритій економіці: теорія, політика, практика : монограсрія / С.А. Романюк. - К. : НАДУ, 2013. - 408 с.

12. Стельмащук А.М. Державне регулювання економіки / А.М. Стельмащук - Тернопіль : ТАНГ, 2000. $315 \mathrm{c}$.

13. Чаленко А.Ю. О понятийной неопределенности термина «механизм» в экономических исследованиях / А.Ю. Чаленко [Электронный ресурс] // Режим доступа : http://archive.nbuv.gov.ua/portal/Soc_ Gum/EProm/2010_51/st_51_04.pdf.

\section{REFERENCES:}

1. Bakumenko V., Knjazjev V., Surmi Ju. (2000) Metodologhija derzhavnogho upravlinnja: problemy stanovlennja ta podaljshogho rozvytku [Methodology of public administration: problems of formation and further development]. Visnyk UADU - UADU Bulletin, no. 1, pp. 11-27.

2. Belkin V.D. (2015) Izbrannye trudy v 3 tomah. Tom 2. Parallel'nyj rubl' i sistemnaja sbalansirovannost' jekonomiki [Selected works in 3 volumes. Volume 2. Parallel ruble and systemic balance of the economy]. Moscow: CJeMI RAN. (in Russian)
3. Berdanova O.V., Vakulenko V.M. (2013) Instrumenty reghionaljnogho rozvytku v Ukrajini [Instruments of regional development in Ukraine]. Kiyv: NADU. (in Ukrainian)

4. Govtvan' O.D., Ivanter V.V., Lejbkind Ju.R., Perlamutrov V.L. (1984) Sbalansirovannost' narodnohozjajstvennyh kompleksov (na primere prodovol'stvennogo kompleksa) [Balance of national economic complexes (on the example of the food complex)]. Moscow: CJeMI AN SSSR. (in Russian)

5. Klejner G.B. (2015) Sistemnaja sbalansirovannost' jekonomiki: metody analiza i izmerenija [Systemic balance of the economy: methods of analysis and measurement]. Strategicheskoe planirovanie i razvitie predprijatij: Sekcija 1 / Materialy Shestnadcatogo vserossijskogo simpoziuma (Moskva, 14-15 aprelja 2015). Moskva : CJeMI RAN, pp. 74-78.

6. Kolpakov V.M. (2003) Metody upravlenija [Management Methods]. Kiyv: MAUP. (in Russian)

7. Kravtsiv V.S. (2017) Terytorialjnyj rozvytok ta reghionaljna polityka $v$ Ukrajini: aktualjni problemy, ryzyky ta perspektyvy administratyvno-finansovoji decentralizaciji [Territorial development and regional policy in Ukraine: current issues, risks and prospects of administrative and financial decentralization]. Ljviv : DU «Instytut reghionaljnykh doslidzhenj imeni M.I. Dolishnjogho NAN Ukrajiny». (in Ukrainian)

8. Muzychenko A.S., Maljugha L.M. (2009) Orghanizacijno-ekonomichnyj mekhanizm stymuljuvannja innovacijnoji dijaljnosti v APK [Organizational and economic mechanism of stimulating innovation in the agroindustrial complex]. Ekonomika APK, no. 11, pp. 38-43.

9. Pliseckij E.L. (2014) Zarubezhnyj i otechestvennyj opyt gosudarstvennoj podderzhki razvitija territorii [Foreign and domestic experience of state support for the development of the territory]. Regional'naja jekonomika: teorija i praktika, № 42(369), pp. 32-44.

10. Rajzberg B.A., Lozovskij L.Sh., Starodubceva E.B. (2006) Sovremennyj jekonomicheskij slovar' [Modern economic dictionary]. Moscow : INFRA-M. (in Russian)

11. Romanjuk S.A. (2013) Rozvytok reghioniv u vidkrytij ekonomici: teorija, polityka, praktyka : monoghrafija [Development of regions in an open economy: theory, policy, practice]. Kiyv : NADU. (in Ukrainian)

12. Steljmashhuk A.M. (2000) Derzhavne reghuljuvannja ekonomiky [State regulation of the economy]. Ternopilj : TANGh. (in Ukrainian)

13. Chalenko A.Ju. (2010) O ponjatijnoj neopredelennosti termina «mehanizm» $v$ jekonomicheskih issledovanijah [On the conceptual uncertainty of the term "mechanism" in economic research]. Available at: http://archive.nbuv.gov.ua/portal/Soc_Gum/ EProm/2010_51/st_51_04.pdf. 